\title{
Breeding biology of the Helmeted Manakin Antilophia galeata in an ecotone between the Atlantic Forest and the Cerrado
}

\author{
Bráulio de Freitas Marçal ${ }^{1}$ \& Leonardo Esteves Lopes ${ }^{2,3}$ \\ 1 Pós-graduação em Manejo e Conservação de Ecossistemas Naturais e Agrários, Universidade Federal de Viçosa, Campus Florestal, Florestal, MG, \\ Brazil. \\ 2 Laboratório de Biologia Animal, Instituto de Ciências Biológicas e da Saúde, Universidade Federal de Viçosa, Campus Florestal, Florestal, MG, \\ Brazil. \\ ${ }^{3}$ Corresponding author: leo.cerrado@gmail.com
}

Received on 22 August 2018. Accepted on 26 March 2019.

\begin{abstract}
Manakins (Pipridae) are well-known by their promiscuous mating system. Nonetheless, scarce evidence suggests that the Helmeted Manakin Antilophia galeata, the only dichromatic manakin widely distributed in the South American Cerrado, is monogamic. We studied the breeding biology of the Helmeted Manakin in the state of Minas Gerais, southeastern Brazil. We found 17 nests, which are built in the forest undergrowth (usually below $3 \mathrm{~m}$ height). Nests are a cup attached by its top lip usually in the angle of a forked branch. The nest attachment zone is made mostly of spider silk. The structural zone is constructed with dry broad leaves, leaf petioles and horsehair fungus, which were bind together by a considerable amount of spider silk. The outer (decorative) zone is made with some hanging dry broad leaves, frequently forming a tail. Clutch size is always two $(n=12)$, and eggs are long oval, with a ground color in different shades of beige, marked with irregular spot, blotches and, sometimes, streaks ranging from light to dark brown. Mean eggs measurements were $23.9 \times 16.3 \mathrm{~mm}(n=14)$, weighting $3.3 \mathrm{~g}(n=10)$. Eggs are laid once each day and hatching is synchronous. Females are the sole responsible for nest building (which usually took 10 days), incubation (18.5 days), and nestling care (18.3 days). The simple percentage of successful nests $(n=11)$ was $27 \%$ and predation was the main cause of nest failure. The breeding season extends from the second half of August to the first half of January. Renesting after loss of a first clutch is a common strategy and we recorded up to three nesting attempts for a single female. We present evidence that the Helmeted Manakin is promiscuous, as usual for a dichromatic manakin.
\end{abstract}

KEY-WORDS: Cerrado, Neotropics, nest, Pipridae, reproduction.

\section{INTRODUCTION}

There are huge knowledge gaps about the breeding biology of birds, especially of those species living in tropical forests (Heming et al. 2013, Xiao et al. 2017). It has been recently demonstrated that most Neotropical bird species have their breeding biology poorly-known $(42.9 \%)$ or only partly-known $(37.9 \%)$, what represents a major impediment to further development of life history theory (Xiao et al. 2017). In addition to the lack of information for some species, the scarce information derived from isolated and superficial observations are frequently biased or even wrong. This is worrying, because the naturalists are dying off (Noss 1996), especially those interested in descriptive natural history, probably because this kind of study is often published in low-impact journals (Beehler 2010, Tewksbury et al. 2014).

A good example of a poorly known tropical forest bird is the Helmeted Manakin Antilophia galeata, a species for which less than a dozen nests have been reported in the literature, most of them superficially described and none properly monitored. Consequently, basic life history parameters for the species, such as incubation and nestling periods, or even sex roles in parental care, are unknown (Marini 1992, Marini et al. 1997, Snow 2004). The range of the Helmeted Manakin is mostly restricted to the Cerrado, one of the largest and most biodiverse biogeographic provinces in the Neotropics, mostly covered by savannas (Silva \& Bates 2002), a kind of habitat not suitable for manakins, which are, as a rule, forest species (Kirwan \& Green 2011). The Helmeted Manakin is fairly common in the gallery forests and patches of semideciduous forests in the Cerrado (Marini \& Cavalcanti 1996, Kirwan \& Green 2011).

The genus Antilophia includes two species, the Helmeted Manakin and the recently described Araripe Manakin A. bokermanni (Kirwan \& Green 2011). The genus is sister to Chiroxiphia (Ohlson et al. 2013), maybe 
congeneric with it (Silva et al. 2018), and there are several reports of hybridization between them (Rezende et al. 2013, Alves et al. 2016). The Helmeted Manakin is a highly dimorphic species, with males predominantly black with a distinctive red crest, nape, and mantle; females, as well as young males, are mostly olive green (Ridgely $\&$ Tudor 2009). Antilophia is considered the only genus of dichromatic manakins with a non-promiscuous mating system (Marini 1992, Marini \& Cavalcanti 1992, Kirwan \& Green 2011). This is a noteworthy and odd behavior for a genus included in an essentially promiscuous family in which males exhibit extraordinary courtship displays in arenas (Snow 2004, Kirwan \& Green 2011). Nevertheless, our field observations revealed that the purported monogamy of the species does not hold true, being a result of scarce and hard to interpret information about the breeding biology of the species. Here we describe in detail the breeding biology of the Helmeted Manakin, also presenting a compilation of previous studies and unpublished data obtained from citizen science networks. With this study we aim to contribute to the understanding of the evolution of life history traits within the Pipridae.

\section{METHODS}

\section{Study area}

We conducted this study in the Universidade Federal de Viçosa - Campus Florestal, municipality of Florestal, state of Minas Gerais, southeastern Brazil. Florestal lies in the transition zone between two important Neotropical biogeographic provinces, the Atlantic Forest and the Cerrado (IBGE 2004), both considered global hotspots of biodiversity (Myers et al. 2000).

We conducted most of the fieldwork in a $\sim 180$ ha forest fragment (centered at $19^{\circ} 52^{\prime} 02^{\prime \prime} S$; $44^{\circ} 25^{\prime} 51^{\prime \prime} \mathrm{W}, 800$ $\mathrm{m}$ a.s.l.) in the very margins of a -13 ha artificial pond ("Represa do Pivô"). There is not perennial creek inside the forest fragments. The forest is semideciduous and secondary, in an intermediate stage of ecological succession (Vieira 2016), with an age of -40 years according to old employees of the university. Mean canopy height is $-10-12$ $\mathrm{m}$ height, with some trees reaching $15 \mathrm{~m}$ or more. We also included in this paper data from opportunistic observations obtained by colleagues in a nearby -65 ha forest fragment with similar age and structure ("Mata dos Equídeos",

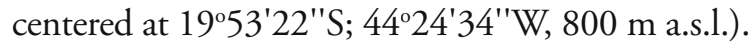

Local climate is subtropical with a mild dry winter and a wet hot summer (Cwa according to the Köppen classification system), with a mean annual temperature of $19.9^{\circ} \mathrm{C}$ (Lopes \& Marçal 2016). Mean annual precipitation is $1447 \mathrm{~mm}$, with a wet season from
October to March and a well-marked dry season from April to September (Lopes \& Marçal 2016).

\section{Capturing, banding, and sexing}

Birds were mist-netted (nets measuring $12 \times 3 \mathrm{~m}$, netting effort of -250.000 h.m ${ }^{2}$ ) from March to September 2016 and received a numbered metallic band from the Brazilian National Center for Bird Conservation and Research (CEMAVE) and a unique combination of three color bands. Given that young males and females are hardly told apart by plumage, we collected a blood sample from greenish birds after puncturing the brachial vein and send it to a private laboratory for molecular sexing (http:// www.unigen.com.br).

\section{Nest searching and monitoring}

We followed banded birds with the aid of $8 \times 42$ binoculars from March to December 2016, while studying the territorial (data not show) and breeding behavior of the species. Opportunistic observations by colleagues were obtained from September to December 2017. During fieldwork, we searched for evidence of breeding activity, such as the transportation of nesting material or food for nestlings that could reveal nest location (Martin \& Geupel 1993). Once found, we briefly monitored nests at two days interval, taking notes on its content (e.g., number of eggs and/or nestlings, stage of development). We spent at least $20 \mathrm{~h}$ observing nest construction $(n=7$ nests) and $10 \mathrm{~h}$ observing nestling care $(n=4)$.

We classified the nest type following the proposal of Simon \& Pacheco (2005) and described it after the proposal of Hansell (2000) for standardizing nest description, taking the following measurements $(\mathrm{mm})$ with a caliper: nest depth, nest diameter, cup depth, cup diameter, and support diameter; the height of the nest in relation to the ground $(\mathrm{cm})$ was measured with a measuring tape. We measured $(\mathrm{mm})$ and weighed $(\mathrm{g})$ the eggs, respectively, with a caliper and a spring scale, and described their shape after Birkhead (2016). Once found, we examined the eggs in the field to determine their approximate incubation stage using the flashlight of a smartphone as a candler (Lokemoen \& Koford 1996).

\section{Literature and citizen science review}

We complemented our field observations with data gathered from the literature and from two of the most important citizen science projects that deal with Neotropical birds, the Internet Bird Collection (http:// www.hbw.com/ibc) and the Wikiaves (http://www. wikiaves.com). All online searches were conducted in April 2018. 


\section{RESULTS}

We captured and banded 38 birds (nine females, 24 definitive plumaged males and five greenish birds that could not be sexed). We found 17 nests (six of them opportunistically found during the 2017 breeding season), 12 of which were monitored. These nests belonged to at least seven distinct females. Eight of the 12 nests monitored were found during its construction and four after the first egg was laid. Five nests were found already built, but they were probably already inactive, because they were abandoned, depredated, or their nestlings fledged before we found them. We identified these nests as belonging to the Helmeted Manakin, which build characteristic nests, based on their similar shape, measurements, and construction material (see below).

During the 2016 breeding season, we found the first nest under construction on 27 September, and the last active nest was observed on 23 December, when its single nestling successfully fledged. During the 2017 breeding season, when observations were opportunistic, we found the first active nest with two eggs on 25 August, and the last active nest was observed on 03 November, when it contained two dead nestlings being eaten by ants. Given the low number of nests found, we can only estimate the length of the breeding season by indirect evidence. A juvenile observed being reared by its mother out of the nest on 06 October 2016 (the entire nesting cycle, from the onset of its construction to fledging, is $-45-50$ days) indicates that the breeding season starts as early as mid-August. A copulation observed on 28 November indicates that the breeding season extends through midJanuary. Therefore, the breeding season of the Helmeted Manakin in the study area extends for about five months, from the second half of August to the first half of January, coinciding with the end of the dry season and the first half of the wet season.

All nests found were in the undergrowth of the forest fragments and were attached to branches of trees or shrubs, ranging from $1.15-5.64 \mathrm{~m}(n=17)$ above the ground (Table 1). Only one nest was close to a water body (15 $\mathrm{m}$ from the margin of the pond), whilst all other nests were at least $25 \mathrm{~m}$ away from water. The six nests found during the 2017 breeding season were at least $150 \mathrm{~m}$ from the nearby water body, which was isolated from the forest fragment by a stretch of artificial pasture.

Females are the sole responsible for nest construction (Fig. 1), an activity that usually took nine days, ranging from eight to ten days $(n=8)$. We observed nest building
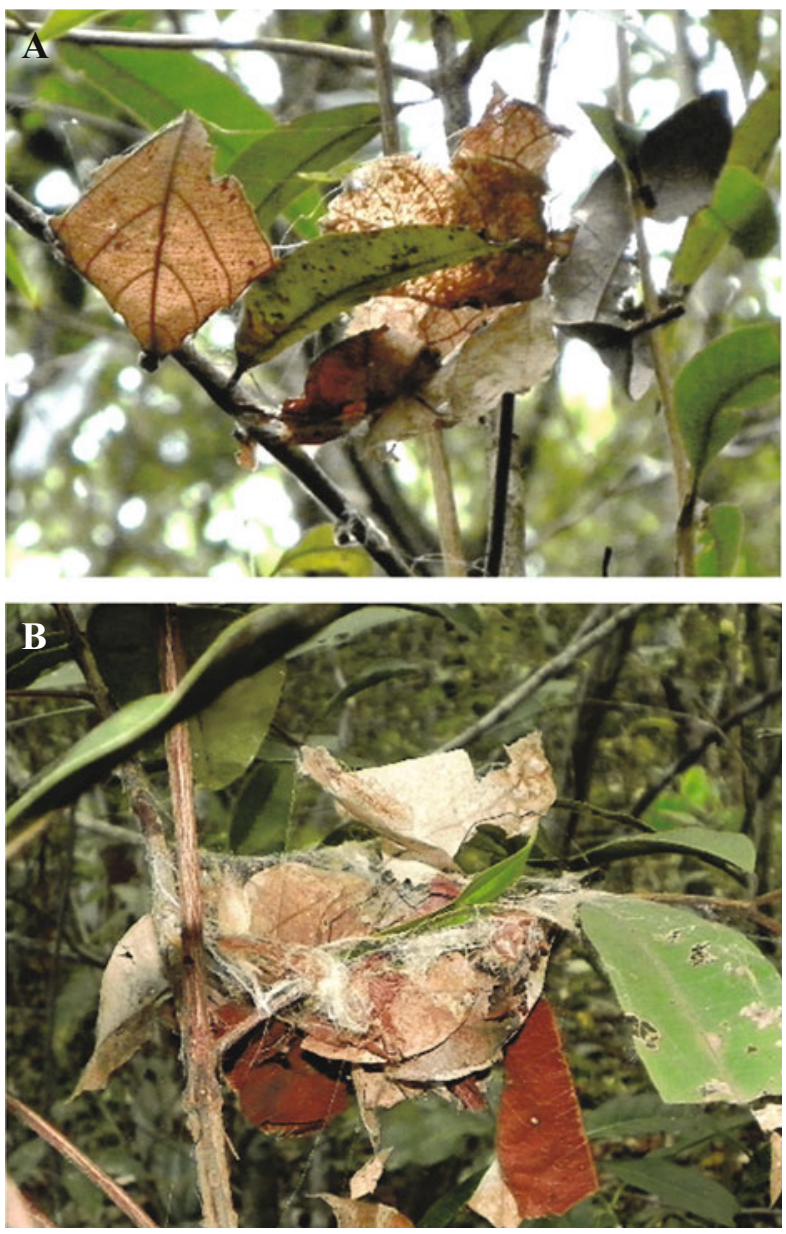

Figure 1. Nest of the Helmeted Manakin Antilophia galeata on the first day of construction, evidencing the large amount of spider silk used to attach the nest to the support plant (A). Note that the first dry broad leaves have already been deposited and that some green broad leaves, still attached to the branch, were being incorporated into the nest. Another nest of the Helmeted Manakin, almost completely built (B). Photo author: B.F. Marçal.

Table 1. Measurements of some nests of the Helmeted Manakin Antilophia galeata found in the municipality of Florestal, Minas Gerais, Brazil. All measurements follow Hansell (2000).

\begin{tabular}{lccccc}
\hline Variable & Mean & Standard deviation & Minimum & Maximum & $\boldsymbol{n}$ \\
\hline Height above ground $(\mathrm{m})$ & 2.3 & 1.18 & 1.15 & 5.64 & 15 \\
Support diameter $(\mathrm{mm})$ & 5.5 & 1.6 & 3.5 & 7.8 & 7 \\
Nest depth $(\mathrm{mm})$ & 41.5 & 9.1 & 27.7 & 55.0 & 9 \\
Cup depth $(\mathrm{mm})$ & 28.5 & 4.8 & 19.7 & 35.3 & 9 \\
Nest diameter $(\mathrm{mm})$ & 66.1 & 7.7 & 53.4 & 75.2 & 9 \\
Cup diameter $(\mathrm{mm})$ & 49.8 & 4.7 & 44.1 & 57.9 & 9 \\
\hline
\end{tabular}


throughout the day, but this activity was seldom recorded during the first hours after dawn, when birds spent most of the time foraging.

The nest, according to the standard classification of Simon \& Pacheco (2005), is a low cup/fork. The nest is best described as a cup attached by its top lip in the angle of a forked branch (Fig. 2), according to the Hansell (2000) standard system. Two nests were built between two parallel branches that were functionally equivalent to a forked branch (Fig. 1). Nest measurements are presented in Table 1. Plants used as support were: Calyptranthes sp. (Myrtaceae, $n=3$ ), Syzygium sp. (Myrtaceae, $n=2$ ), Amaioua sp. (Rubiaceae, $n=2)$, and Rubiaceae sp. $(n=$ 4). It was not possible to identify the support plant of the other six nests.

Nests (Figs. 2 \& 3) show three well-delimited zones: attachment, structural, and decorative. The nest was attached to the fork mostly with spider silk. The structural zone is constructed with dry broad leaves, leaf petioles, and horsehair fungus (Marasmius), which
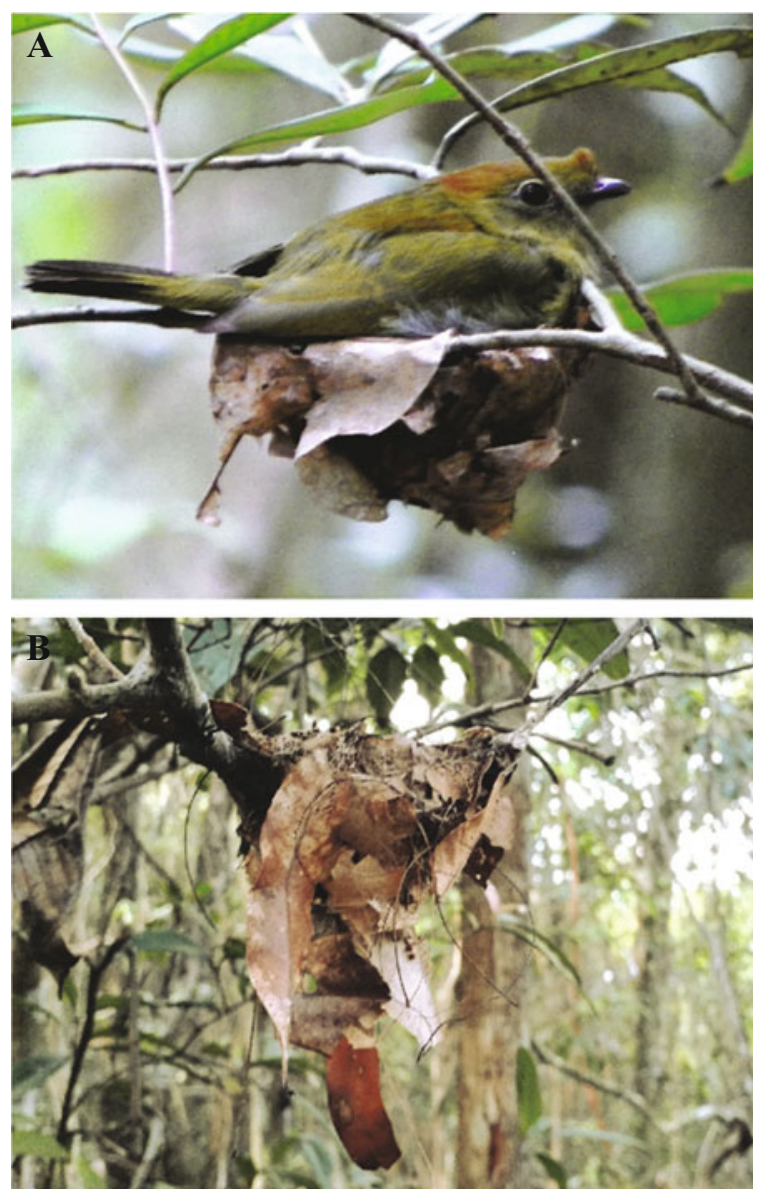

Figure 2. Female Helmeted Manakin Antilophia galeata incubating its eggs (A). Note that the crest, nape and back of this bird is slightly washed with red, what suggests that it is an old female, as previously reported for the species (Marini 1989) and members of Chiroxiphia (Kirwan \& Green 2011). Side view of another nest, showing a long tail made of dry leaves, leaf petioles, and horsehair fungus hanging on its outer walls and lower part (B). Photo author: B.F. Marçal. are bind together by a considerable amount of spider silk (scored as two in a three-point scale, as suggested by Hansell 2000). Sometimes, green broad leaves, still attached to the branch, are also incorporated into the structural zone (Fig. 1). The inner layer of the structural zone, i.e., that which is in contact with the eggs, is built with thin leaf petioles and unidentified vegetable fibers. The decorative (outer) zone is made of some few hanging dry broad leaves, frequently forming a tail (Fig. 2).

Spider silk was collected within a radius of -100 $\mathrm{m}$ from the construction site, as suggested by the several observations of females collecting material for nest construction. At each visit in which she brings material, the female sits in the unfinished nest and, with the wings held close to the body, she makes circular movements in the nest, shaping it with her legs while compressing the nest material with her breast and flanks. The female then perches on the edge of the nest and arranges the leaves and petioles with its beak, sits again in the nest and compresses and shapes the newly added material
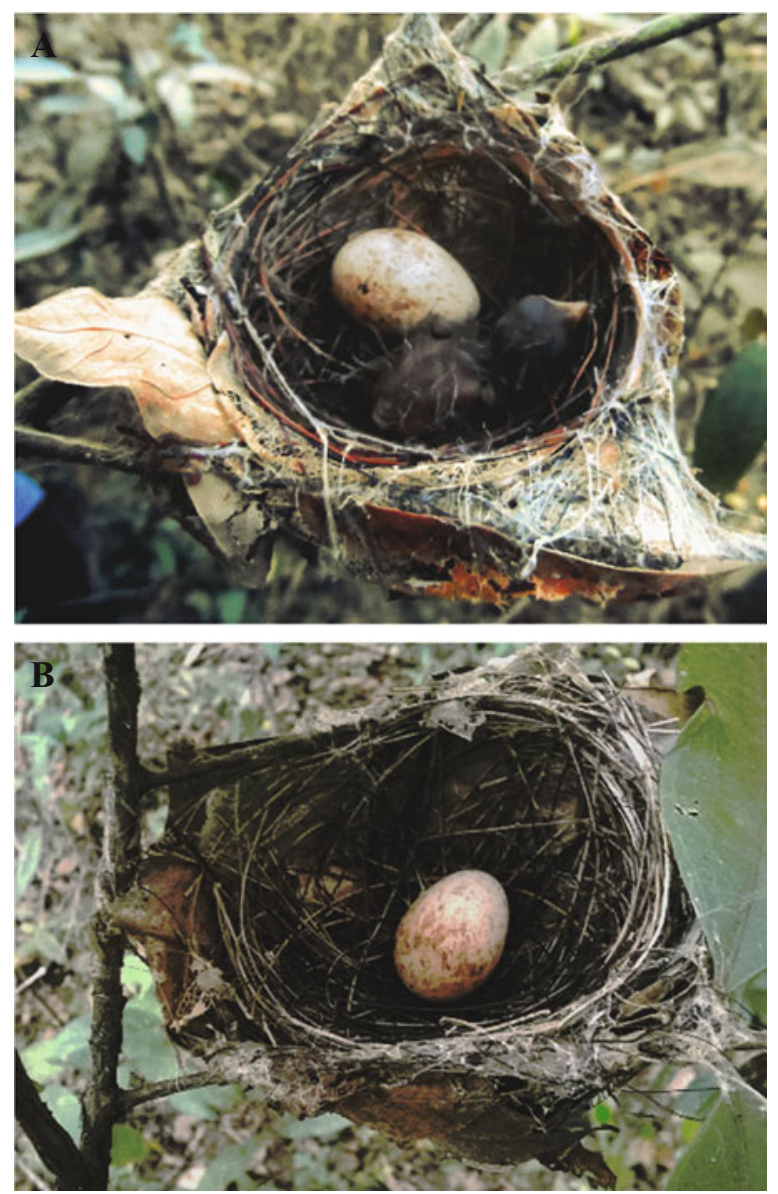

Figure 3. The nest of the Helmeted Manakin Antilophia galeata with an egg and a freshly hatched nestling. Nests of this species are a cup attached by its top lip in the angle of a forked branch (A). Nest constructed between two nearby parallel branches, evidencing the presence of leaf petioles and some unidentified vegetable fibers in the inner layer of the structural zone $(\mathbf{B})$. Photo author: D.F. Ferreira (A) \& B.F. Marçal (B). 
against the walls of the nest. During this process some dry broad leaves and horsehair fungus fall apart from the nest, hanging from the lower part of the nest. These leaves are not removed, but fixed loosely with additional spider silk, thus forming the nest tail.

Clutch size was always two eggs $(n=12)$, which are long oval, with ground color in different shades of beige, and marked with a highly variable patterning of spots, blotches and, frequently, streaks ranging from light to dark brown (Figs. $3 \& 4$ ). Egg patterning can be concentrated around the larger pole or homogeneously distributed throughout the egg surface. Eggs measured $23.9 \pm 0.6 \mathrm{~mm}(23.2-25.4 \mathrm{~mm}, n=14) \times 16.3 \pm 0.3 \mathrm{~mm}$ $(15.8-16.9 \mathrm{~mm}, n=14)$ and weighted $3.3 \pm 0.2 \mathrm{~g}(3.0$ $3.6 \mathrm{~g}, n=10)$. The first egg is laid on the first or second day after nest building is complete, with the second egg laid on the following day $(n=9)$. Incubation is performed by the female alone, during a mean incubation period of 18.5 days $(18-19, n=7)$. The onset of incubation is delayed until all eggs are laid, resulting in synchronous hatching.

Only the female brood and feed the nestlings. The nest is constantly kept clean, with females ingesting the regurgitated seeds and fecal sacs (video at http://hbw. com/ibc/1365115), which are usually regurgitated far away from the nest. Nestlings older than 10 days usually regurgitate seeds straight on the ground, what results in the accumulation of a large amount of seeds just below the nest (Fig. 5). Juvenile fledge after $18.3 \pm 1.15$ days $(17-19, n=3)$, but the female still feed them out of the nest for at least 10 days.

Renesting after loss of a first clutch is common, and at least three breeding attempts in a single breeding season have been recorded, as indicated by indirect evidence. One of the banded females monitored was seen carrying material to construct its nest at the last

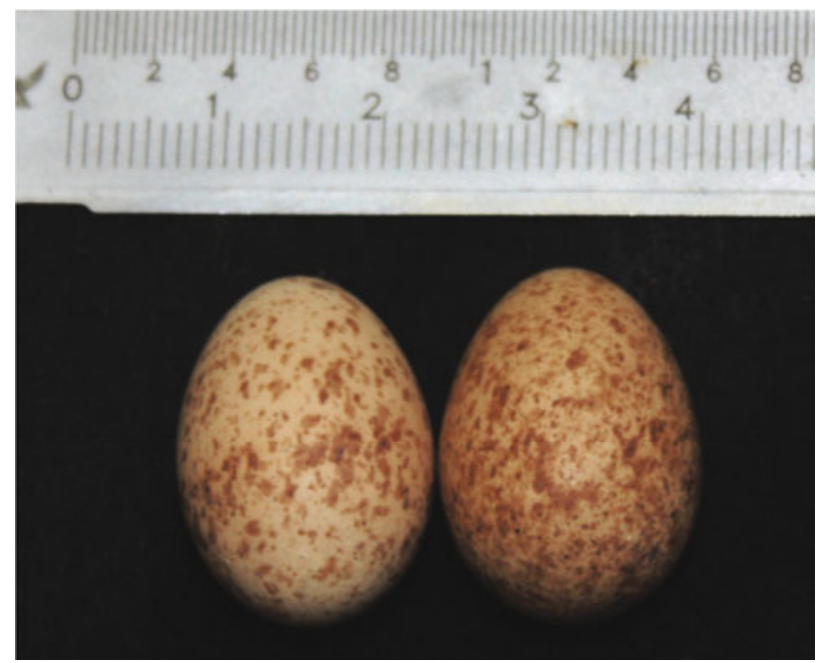

Figure 4. Two eggs of the Helmeted Manakin Antilophia galeata belonging to the same clutch. Note the marked chromatic differences between them. Photo author: L.J. Ferreira. days of September 2016, with eggs hatching on 23 October. We waited four days after hatching to band the nestlings, but, unexpectedly, the female held them by the tarsus with its beak and removed them from the nest, one by one, carrying them to a distant place, where they were abandoned and died (video at http://hbw.com/ ibc/1384202). After this event we decided not to handle the nestlings anymore. Two days after the occurrence, the female began issuing short calls with one or two notes (http://www.wikiaves.com/2574665 and http://www. wikiaves.com/2574636), which caused the appearance of four males, probably seeking a mate, but no copulation was observed. We found on 09 November the second nest of the same female, already with two eggs, only 13 days after the previous clutch become inactive. This nest was depredated 16 days after we found it, on 25 November. This female was only sighted again on 28 November, again accompanied by four males, while issuing the same short calls described earlier. On the same day this female copulated with a definitive plumaged male that was engaged in the chasing displays discussed below, what indicates a third attempt of reproduction, even thought we did not find this third nest. This was the only copula we observed,

Of the 11 nests monitored (excluding the one lost due to observer interference), one was abandoned during construction stage, five were depredated during incubation, two were depredated with nestlings, and only three were successful (27\% apparent success). One of the successful nests produced two juveniles, while the other two nests produced only one juvenile, because one egg in each disappeared during incubation stage. Three of the five nests that we found already built probably harbored nestlings in an advanced stage of development, as attested by the large number of regurgitated seeds below them.

Our bibliographic review revealed 10 nests of the species previously reported in the literature, two of them

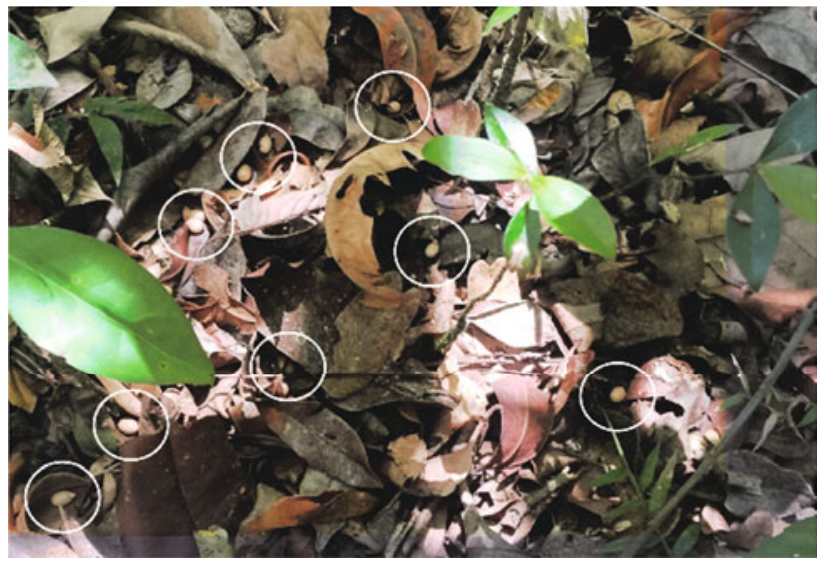

Figure 5. Regurgitated seeds accumulated under a nest of the Helmeted Manakin Antilophia galeata. Some of the more than 100 seeds found were highlighted by a white circle. Photo author: B.F. Marçal. 
consisting only of a color photograph, unaccompanied by any additional information. We also found 11 breeding records of the species in the citizen science networks consulted (Table 2).

\section{DISCUSSION}

The breeding season of the Helmeted Manakin in the study area extends from mid-August to mid-January, coinciding with the period observed or inferred from indirect evidences throughout its range (Table 2). This suggests that the time of breeding in the species varies little along its wide geographical distribution, what is probably related to the relative similarity of climate throughout the Cerrado, especially in relation to the timing of the wet season (Nimer 1989, Alvares et al. 2013).

The breeding season of members of Antilophia and Chiroxiphia begin at the end of the dry season and extends through the first half of the wet season, irrespective of the region and habitat occupied. The breeding season of the Blue Manakin Chiroxiphia caudata in a primary submontane rain forest in the Brazilian Atlantic Forest lasted about five months, extending from October to February (Zima et al. 2017). Similarly, the breeding season of the Long-tailed Manakin Chiroxiphia linearis in

Table 2. A compilation of breeding records of the Helmeted Manakin Antilophia galeata obtained from the literature* or from the following citizen science websites Wikiaves (WA) and Internet Bird Collection (IBC). Except when indicated, all records are from Brazil.

\begin{tabular}{|c|c|c|c|}
\hline Date & Place of record & Type of record & Source \\
\hline- & Brasília, Distrito Federal & Abandoned nest. & Sick (1958) \\
\hline- & Minas Gerais & Nest with eggs. & Snow (2004) \\
\hline- & "central Brazil" & Nest with two eggs. & Buzzetti \& Silva (2005) \\
\hline 04 Sep & Vargem Grande do Sul, São Paulo & Nest with incubating female. & WA 1073140 \\
\hline 07 Sep & Uberlândia, Minas Gerais & Nest with two eggs. & Marini et al. (1997) \\
\hline 26 Sep & Serranía de Huanchaca, Santa Cruz, Bolivia & Female with egg in oviduct. & Bates et al. (1992) \\
\hline 26 Sep & Uberlândia, Minas Gerais & Nest with two nestlings. & Marini et al. (1997) \\
\hline Oct & São Paulo & Nest with two eggs. & von Ihering (1900) \\
\hline Oct & Brasília, Distrito Federal & Female with egg in oviduct. & Marini (1992) \\
\hline Oct & Brasília, Distrito Federal & Nest with two eggs. & Marini (1992) \\
\hline 13 Oct & Brasília, Distrito Federal & Nest with two eggs. & Marini (1992) \\
\hline 09 Oct & Brasília, Distrito Federal & Nest with two nestlings. & Marini (1992) \\
\hline $10 \mathrm{Oct}$ & Brasília, Distrito Federal & Nest with two eggs. & WA 1224919 \\
\hline 11 Oct & Florestal, Minas Gerais & Nest with two eggs. & WA 2887907 \\
\hline 13 Oct & Chapada dos Guimarães, Mato Grosso & Nest with two eggs. & Allen et al. $(1893)^{* *}$ \\
\hline Nov & Brasília, Distrito Federal & Female with egg in oviduct. & Marini (1992) \\
\hline $02 \mathrm{Nov}$ & Carmópolis de Minas, Minas Gerais & Female carrying nest material. & WA 2767569 \\
\hline $12 \mathrm{Nov}$ & Uberlândia, Minas Gerais & Nest with two eggs. & Marini et al. (1997) \\
\hline $14 \mathrm{Nov}$ & Brotas, São Paulo & Nest with incubating female. & WA 508697 \\
\hline 19 Nov & Paracatu, Minas Gerais & Nest with incubating female. & WA 1524895 \\
\hline $03 \mathrm{Dec}$ & Brasília, Distrito Federal & Nest with incubating female. & WA 513118 \\
\hline $08 \mathrm{Dec}$ & Pará de Minas, Minas Gerais & Nest with two fledglings. & WA 646945 \\
\hline $10 \mathrm{Dec}$ & São Roque de Minas, Minas Gerais & Nest with incubating female. & WA 2428180 \\
\hline $12 \mathrm{Dec}$ & Batatais, São Paulo & Nest with two eggs. & von Ihering $(1902)^{* * *}$ \\
\hline $21 \mathrm{Dec}$ & Chapada Diamantina, Bahia & Nest with one nestling. & IBC 1196099 \\
\hline $25 \mathrm{Dec}$ & Alto Paraíso de Goiás, Goiás & Nest with incubating female. & WA 1588195 \\
\hline
\end{tabular}

*Marini (1992) reports that females collected and/or mist-netted in Brasília by him exhibited brood patch from September to December; males with enlarged testes were collected from July to December.

** The eggs of this clutch are deposited at the American Museum of Natural History, New York, USA (AMNH 14439, M.Â.M., pers. comm.).

*** This nest is deposited at Museu de Zoologia da Universidade de São Paulo, São Paulo, Brazil (MZUSP 900) and one of the eggs is probably an egg deposited at the Museum für Naturkunde, Berlin, Germany (ZMB 1433, M.Â.M., pers. comm.). 
a riparian woodland within a disturbed tropical dry forest in Costa Rica also lasted for about five months, extending from March to July (Foster 1976). Therefore, the length of the breeding season is remarkably similar for the Helmeted Manakin and the two species of Chiroxiphia that occupy quite distinct habitats.

Nest placement and its morphology, as well as life history parameters, are quite uniform between members of Antilophia and Chiroxiphia. The Helmeted Manakin nests in the undergrowth, usually below $3 \mathrm{~m}$, using both shrub and trees as support, even though some nests can be built as high as $10 \mathrm{~m}$ (Marini 1992). Linhares et al. (2010) found similar result for the 28 nests of the Araripe Manakin A. bokermanni, with $93 \%$ of them constructed below $2 \mathrm{~m}$. The Blue Manakin and the Longtailed Manakin also construct their nests in the forest undergrowth, usually below $3 \mathrm{~m}$, although they also show substantial variation in nesting height (Foster 1976, Zima et al. 2017). Nests of all species in these two genera are a cup attached by its top lip in the angle of a forked branch, often including a tail of loose dry broad leaves (Kirwan \& Green 2011). Other similarities in breeding parameters between Antilophia and Chiroxiphia are: clutch size of two eggs, incubation performed exclusively by females during a period of $\sim 18$ days, nests kept clean, and nestlings brooded and feed exclusively by females for a period of -16 days (Foster 1976, Coelho \& Silva 1998, Silva 2004, Linhares et al. 2010, Zima et al. 2017).

Low reproductive success such as that recorded for the Helmeted Manakin (27\%) was also recorded for other passerine birds in our study area. For example, the simple percentage of successful nests for the syntopic Pale-bellied Tyrant-manakin Neopelma pallescens (Pipridae) was as low as $15.4 \%(n=13$; Ferreira \& Lopes 2018). Slightly higher percentage of successful nests was recorded for the forest edge Gray-headed Tody-Flycatcher Todirostrum poliocephalum (Rhynchocyclidae) (30.8\%, $n=13$; Ferreira et al. 2019) and for the open area Lined Seedeater Sporophila lineola (Thraupidae) (36.5\%, $n=74$; Ferreira \& Lopes 2017).

Members of Antilophia and Chiroxiphia, although closely related, present quite distinct courtship displays. Males of Chiroxiphia usually congregate in fixed arenas where they exhibit complex courtship displays to impress females (Kirwan \& Green 2011). The Helmeted Manakin has no fixed territory during the breeding season, but rather, range widely along its home range, seeking sexually receptive females. Multiple males them congregate near a receptive female and exhibit an unspectacular chasing courtship display (Marçal 2017). These chasing displays have already been described by previous authors for the Helmeted Manakin (Sick 1967, 1997, Marini \& Cavalcanti 1992) and the Araripe Manakin (Silva \& Rêgo 2004), but they have never been properly interpreted as such.
Data summarized here indicates that the Helmeted Manakin is not a monogamic species as previously suggested (Marini 1992, Marini \& Cavalcanti 1992, Kirwan \& Green 2011), but a promiscuous one, with males potentially copulating with any receptive female, but without providing any paternal care. Doubts about the true mating system of the Helmeted Manakin were expressed by Marini \& Cavalcanti (1992), who stated that the species was "possibly monogamous", but that "several possible problems with this interpretation" existed.

The hypothesis of promiscuity presented here can only be unequivocally confirmed with an investigation of genetic paternity of nestling associated with closer observations of copulations in the field. The study of DuVal \& Kempenaers (2008), for example, demonstrated that in the Long-tailed Manakin nestlings were overwhelmingly sired by alpha males.

The fact that most of the nests found in our study area were far from water shows that breeding in the Helmeted Manakin is not restricted to the riparian forests of the Cerrado, and that it can reproduce in areas with no water body at all. Several studies found the species inhabiting small forest fragments in degraded environments, revealing the plasticity and versatility of the species in relation to its habitat use (Andrade \& Marini 2002, Ferreira \& Cavalcanti 2005, Manica et al. 2010). The data summarized here, although obtained during a short-term study, provided evidence of a promiscuous breeding system and a high capacity of adaptation to different habitats by the Helmeted Manakin, which is threatened by climate changes (Anciáes \& Peterson 2006, Marini et al. 2009).

\section{ACKNOWLEDGEMENTS}

B.M.F. received a scholarship from CAPES and L.E.L. received a research fellowship from $\mathrm{CNPq}$ (305401/20149). Banding and collecting permits were provided, respectively, by CEMAVE (4090/2) and ICMBio (23439-2). This study complies with all ethical standards for research (CEUA-UFV 50/2016). CAF-UFV allowed us to conduct this study in the area under their care. Gustavo Martins, Manoella Morais, Luana Ferreira, and Dalila Ferreira helped during fieldwork. Elias Roma helped with botanical identification. Miguel Ângelo Marini, Guilherme Freitas and Lílian Costa presented useful comments on an earlier version of this paper.

\section{REFERENCES}

Allen J.A., Smith H.H. \& Smith W.C. 1893. On a collection of birds from Chapada, Matto Grosso, Brazil, made by Mr. H.H. Smith: part 3, Pipridae to Rheidae. Bulletin of the American Museum of Natural History 5: 107-158. 
Alvares C.A., Stape J.L., Sentelhas P.C., de Moraes G., Leonardo J. \& Sparovek G. 2013. Köppen's climate classification map for Brazil. Meteorologische Zeitschrift 22: 711-728.

Alves W.B., Albano C., Silva W.A.G., Araripe J. \& Rego P.S. 2016. Confirmation of the hybridization of Chiroxiphia Cabanis, 1847 and Antilophia Reichenbach, 1850 (Passeriformes: Pipridae) using molecular markers. Revista Brasileira de Ornitologia 24: 185-190.

Anciães M. \& Peterson A.T. 2006. Climate change effects on Neotropical manakin diversity based on ecological niche modeling. Condor 108: 778-791.

Andrade R.D. \& Marini M.Â. 2002. Bird species richness in natural forest patches in southeast Brazil. Lundiana 3: 141-149.

Bates J.M., Parker-III T.A., Capparella A.P. \& Davis T.J. 1992. Observations on the campo, Cerrado and forest avifaunas of eastern Dpto. Santa Cruz, Bolivia, including 21 species new to the country. Bulletin of the British Ornithologists' Club 112: 86-98.

Beehler B.M. 2010. The forgotten science: a role for natural history in the twenty-first century? Journal of Field Ornithology 81: 1-4.

Birkhead T. 2016. The most perfect thing: inside (and outside) of a bird's egg. London: Bloomsbury.

Buzzetti D \& Silva S. 2005. Berços da vida: ninhos de aves brasileiras. Sáo Paulo: Terceiro Nome.

Coelho G. \& Silva W. 1998. A new species of Antilophia (Passeriformes: Pipridae) from Chapada do Araripe, Ceará, Brazil. Ararajuba 6: 81-84.

DuVal E.H. \& Kempenaers B. 2008. Sexual selection in a lekking bird: the relative opportunity for selection by female choice and male competition. Proceedings of the Royal Society of London B: Biological Sciences 275: 1995-2003.

Ferreira D.F., Aquino M.M., Heming N.M., Marini M.Â., Leite F.S.F. \& Lopes L.E. 2019. Breeding in the Gray-headed Tody-Flycatcher (Aves: Tyrannidae) with comments on geographical variation in reproductive traits within the genus Todirostrum. Journal of Natural History 53: 595-610.

Ferreira A.A. \& Cavalcanti R.B. 2005. Abundância e uso de habitat em florestas de galeria por Antilophia galeata Lichtenstein, 1823 (Aves, Pipridae). Revista de Biologia Neotropical 2: 37-41.

Ferreira D.F. \& Lopes L.E. 2017. Natural history of the Lined Seedeater Sporophila lineola (Aves: Thraupidae) in southeastern Brazil. Journal of Natural History 51: 1425-1435.

Ferreira L.J. \& Lopes L.E. 2018. Breeding biology of the Pale-bellied Tyrant-manakin Neopelma pallescens (Aves: Pipridae) in southeastern Brazil. Journal of Natural History 52: 1893-1908.

Foster M.S. 1976. Nesting biology of the Long-tailed Manakin. Wilson Bulletin 88: 400-420.

Hansell M. 2000. Bird nests and construction behaviour. Cambridge: University Press.

Heming N.M., Greeney H.F. \& Marini M.Â. 2013. Breeding biology research and data availability for New World flycatchers. Natureza \& Conservação 11: 54-58.

IBGE. 2004. Mapa de biomas do Brasil: primeira aproximação. Rio de Janeiro: Instituto Brasileiro de Geografia e Estatística (Access on http://geoftp.ibge.gov.br/informacoes_ambientais/estudos_ ambientais/biomas/mapas/biomas.pdf).

Kirwan G.M. \& Green G. 2011. Cotingas and manakins. Princeton: Princeton University Press.

Linhares K.V., Soares F.A. \& Machado I.C.S. 2010. Nest support plants of the Araripe Manakin Antilophia bokermanni, a critically endangered endemic bird from Ceará, Brazil. Cotinga 32: 121125.

Lokemoen J.T. \& Koford R.R. 1996. Using candlers to determine the incubation stage of passerine eggs. Journal of Field Ornithology 67: 660-668.

Lopes L.E. \& Marçal B.F. 2016. Avifauna do Campus Florestal da Universidade Federal de Viçosa, Minas Gerais, Brasil. Atualidades Ornitológicas 193: 41-56.
Manica L.T., Telles M. \& Dias M.M. 2010. Bird richness and composition in a Cerrado fragment in the state of São Paulo. Brazilian Journal of Biology 70: 243-254.

Marçal B.F. 2017. História natural de Antilophia galeata (Lichtenstein, 1823) (Aves: Pipridae) com ênfase na sua biologia reprodutiva. MSc. Dissertation. Florestal: Universidade Federal de Viçosa.

Marini M.Â. 1989. Seleção de habitat e socialidade em Antilophia galeata (Aves: Pipridae). MSc. Dissertation. Brasília: Universidade de Brasília.

Marini M.Â. \& Cavalcanti R.B. 1992. Mating system of the Helmeted Manakin (Antilophia galeata) in central Brazil. Auk 109: 911-913.

Marini M.Â. \& Cavalcanti R.B. 1996. Influência do fogo na avifauna do sub-bosque de uma mata de galeria do Brasil central. Revista Brasileira de Biologia 56: 749-754.

Marini M.Â. 1992. Notes on the breeding and reproductive biology of the Helmeted Manakin. Wilson Bulletin 104: 168-173.

Marini M.Â., Barbet-Massin M., Lopes L.E. \& Jiguet F. 2009. Predicted climate-driven bird distribution changes and forecasted conservation conflicts in a Neotropical savanna. Conservation Biology 23: 1558-1567.

Marini M.Â., Pereira M.F., Oliveira G.M. \& Melo C. 1997. Novos registros de ninhos e ovos de três espécies de aves do Brasil central. Ararajuba 5: 244-245.

Martin T.E. \& Geupel G.R. 1993. Nest-monitoring plots: methods for locating nests and monitoring success. Journal of Field Ornithology 64: 507-519.

Myers N., Mittermeier R.A., Mittermeier C.G., Fonseca G.A. \& Kent J. 2000. Biodiversity hotspots for conservation priorities. Nature 403: 853-858.

Nimer E. 1989. Climatologia no Brasil. Rio de Janeiro: Instituto Brasileiro de Geografia e Estatística.

Noss R.F. 1996. The naturalists are dying off. Conservation Biology 10: $1-3$.

Ohlson J.I, Fjeldså J. \& Ericson P.G. 2013. Molecular phylogeny of the manakins (Aves: Passeriformes: Pipridae), with a new classification and the description of a new genus. Molecular Phylogenetics and Evolution 69: 796-804.

Rezende M.A., Vasconcelos M.F., Nogueira W., Silva J.C., Becho D.P., Silva L.F. \& Souza T.O. 2013. Novas ocorrências de híbridos entre Chiroxiphia caudata e Antilophia galeata em Minas Gerais, Brasil, com a primeira descrição de uma fêmea híbrida e comentários sobre os riscos da hibridação. Atualidades Ornitológicas 174: 3339.

Sick H. 1958. Resultados de uma excursão ornitológica do Museu Nacional a Brasília, novo Distrito Federal, Goiás, com a descrição de um novo representante de Scytalopus (Rhinocryptidae, Aves). Boletim do Museu Nacional do Rio de Janeiro 185: 1-41.

Sick H. 1967. Courtship behaviour in the manakins (Pipridae): a review. Living Bird 6: 5-22.

Sick H. 1997 Ornitologia brasileira. Rio de Janeiro: Nova Fronteira.

Silva J.M.C. \& Bates J.M. 2002. Biogeographic patterns and conservation in the South American Cerrado: a tropical savanna hotspot. BioScience 52: 225-234.

Silva S.M., Agne C.E., Aleixo A. \& Bonatto S.L. 2018. Phylogeny and systematics of Chiroxiphia and Antilophia manakins (Aves, Pipridae). Molecular Phylogenetics and Evolution 127: 706-711.

Silva W.A.D.G. 2004. Determinação do periodo reprodutivo de Antilophia bokermanni Coelho e Silva, 1998 (Aves: Pipridae) através da vocalização e comportamentos relacionados na Chapada do Araripe-CE. MSc. Dissertation. Recife: Universidade Federal de Pernambuco.

Silva W.A.G. \& Rêgo P.S. 2004. Conservação do Soldadinho-do-Araripe Antilophia bokermanni (Aves: Pipridae): subsidios para a elaboração do plano de manejo. Curitiba: Fundação O Boticário de Proteção à Natureza. 
Simon J.E. \& Pacheco S. 2005. On the standardization of nest descriptions of Neotropical birds. Revista Brasileira de Ornitologia 13: $143-154$.

Snow D. 2004. Family Pipridae (manakins), p. 110-169. In: del Hoyo J., Elliott A. \& Sargatal J. (eds.). Handbook of the birds of the world, v. 9 (cotingas to pipits and wagtails). Barcelona: Lynx Editions.

Tewksbury J.J., Anderson J.G.T., Bakker J.D., Billo T.J., Dunwiddie P.W., Groom M.J. \& del Rio C.M. 2014. Natural history's place in science and society. BioScience 64: 300-310.

Vieira L.M.G. 2016. Efeito de borda na estrutura de fragmentos de floresta estacional semidecidual de diferentes tamanhos na bacia do Rio Paraopeba, MG. MSc. Dissertation. Florestal: Universidade Federal de Viçosa. von Ihering H. 1900. Catálogo crítico-comparativo dos ninhos e ovos das aves do Brasil. Revista do Museu Paulista 4: 191-300.

von Ihering H. 1902. Contribuição para o conhecimento da ornitologia de São Paulo. Revista do Museu Paulista 5: 261-329.

Xiao H., Hu Y., Lang Z., Fang B., Guo W., Zhang Q., Pan X. \& Lu X. 2017. How much do we know about the breeding biology of bird species in the world? Journal of Avian Biology 48: 513-518.

Zima P.V.Q., Perrella D.F., Biagolini-Jr C.H., Ribeiro-Silva L. \& Francisco M.R. 2017. Breeding behavior of the Atlantic Forest endemic Blue Manakin (Chiroxiphia caudata). Wilson Journal of Ornithology 129: 53-61.

Associate Editor: Carla S. Fontana. 